\title{
Public-Private Partnership: An Analysis of the Legal Features of PPP Instrument in the Albanian Reality
}

\author{
Artan Spahiu
}

\begin{abstract}
Ensuring high productivity in public services has been required to be achieved by reducing costs and at the same time by raising standards. This is indeed a challenge intended for which the public sector has turned its eyes on the market. The latter's mechanisms and management methods used by the private sector in the production and delivery of services have become the management philosophy that has characterized public sector reforms in recent decades. Nowadays the main objectives of public sector organizations are to reduce costs and increase the efficiency of operations, which has steered these organizations towards the outsourcing model. Transferring or subcontracting a private entity for some of the operations of public institutions is a concept already known to public sector managers. Heads of various public institutions see the transfer of part of their operations or all operations to private entities as the proper way to provide added value public services. One of the widely used ways of engaging private parties in public projects is the Public Private Partnership (PPP). Implementation of this public-private partnership ensures immediate service availability, debt and public budget avoidance, management, technology and higher performance in service standards and contract enforcement. This type of engagement requires a great deal of attention to the legal framework in order for the private sector to participate in public affairs and services in a regular and reasonable manner and also in order to protect the public interest, maximize the value for money and ensuring appropriate risks sharing.
\end{abstract}

Index Terms-Public-Private Partnership, Law, Public Organizations, Efficiency.

\section{Introduction - The Need for Public-Private PARTNERSHIP}

As with many other concepts, there is not much consensus regarding the definition of the "quality" of public service and even more on the roads that lead to it. Focusing on the citizen, identifying current or future needs, meeting those needs, responding in a due time and effective manner, seting up written standards for the service provided, transparency, simplicity, clarity, free access, all these somehow constitute some of the objectives widely agreed to be achieved in order to affect the "quality" of public service.

Public organizations, as those responsible for providing these services, often have to acrobatize in their efforts to accomplish all of the above while simultaneously acting carefully within the rigid frameworks of public administration. This is because pursuing the "public interest" requires services to be designed around user needs

Published on March 24, 2020.

A. Spahiu, Department of Law, Faculty of Economics, University of Elbasan "Aleksandër Xhuvani", Albania.

(email: artan_spahiu@yahoo.com; artan.spahiu@uniel.edu.al) rather than around what may currently be considered appropriate for the service provider. On the other hand, the public sector is increasingly faced with rising costs, so one of the main concerns of any government is to reduce public spending.

Precisely the need to face the public service spending cuts, their rigid and centralized government control, the inadequacy of public investment, the need to be elastic in dealing with market requirements and to provide a good service, has necessitated the seek for new methods for the production and distribution of public services. This need has brought to light new concepts such as new public management, which focuses inter alia on the use of private sector market mechanisms to bring about changes in public service management ${ }^{1}$.

In order to achieve the public service quality objectives, the public sector has had not only to adapt the management methods borrowed from the private sector but also to invite the latter directly into the production or distribution of public services. This is precisely what has led to the creation of what is widely regarded as the Public Private Partnership. In this case, the division of responsibilities between the private and public sectors is done properly, leaving to the latter the role of the regulator and to the private sector the role of the services provider. In this way we can increase the level of service for infrastructure users, reach the effectiveness of operations and improve the distribution of limited public funds. Regarding these public-private collaborative projects, the public sector concern relates mainly to the apparent differences of interest of each of these two sectors.

\section{What Is a Public Private Partnership?}

There is not a single commonly accepted definition of Public-Private-Partnerships, which can sometimes make it difficult to evaluate and compare with international experiences. In fact, with reference to the literature, "PPP" is defined differently by academics, public institutions or international organizations2. Common elements that describe all of these definitions are: cooperation, sharing of responsibilities, sharing of risk, mutual benefit, pursuit of

\footnotetext{
${ }^{1}$ OECD (1993): Public Menagement Development Survey. Paris

The term "partnership" includes contractual agreements, cooperative agreements, joint activities, used to develop policies, support programs, and distribute government programs and services (Osborne, 2000). Publicprivate partnership is a relationship that consists of common and/or shared objectives as well as a distribution of specific roles and responsibilities among participants, a relationship that may be formal, informal, contractual or voluntary, between two or more parties. There is a shared investment in resources and consequently a shared risk, authority and benefit for all partners (Lewis, 2002).
} 
common or shared objectives, joint investment. The European Commission through its Guide to a Successful Public Private Partnership (2003) has identified the important role of the private sector in PPP schemes in several aspects and in particular $^{3}$ :providing additional capital; providing alternative managerial and implementation skills; providing value added to the consumer and the public; better identification of needs and optimal use of resources.

Public-private partnerships generally refer to forms of cooperation between public authorities and the private sector that are intended to provide financing, construction, renovation, management, operation and/or maintenance of infrastructure and/or service provision. In essence, all public-private partnerships involve some form of risk sharing between the public and private sectors, in the provision of infrastructure or services. Risk sharing for the private partner is the determinant key of the difference between the PPP and the traditional public procurement model of public service delivery.

Despite the fact that there is no universal consensus on the definition of public-private partnerships, there is consensus on the elements that characterize PPPs:

- PPPs are typically contractual agreements between the public sector and the private sector for the provision of infrastructure and public services or other basic services.

- The infrastructure or service is funded, in whole or in part, by the private partner.

- Risks are shared between the public partner and the private one, making the division to the party best positioned to manage each individual risk.

- $\quad$ PPPs are a public procurement instrument, focusing on payment for the successful delivery of services to the public (transfer of performance risk to the private partner).

- PPPs are "output" or performance based agreements (the traditional model of public service delivery is based on "input").

- PPPs typically include "grouped" services (eg, design, construction, maintenance and operation) in order to maximize synergy and not encourage low capital proposals with high operating costs ${ }^{4}$.

\section{Public - Private Partnership in Albania}

In Albania, the Constitution itself pays special attention to public spending, which means the effectiveness and efficiency of the use of public funds ${ }^{5}$ in the activity of state bodies. This is because such activity is itself carried out within the general economic system of the Republic of

\footnotetext{
${ }^{3}$ European Commission 2003: Guidelines for successful public-private partnership

${ }^{4}$ Introduction to Public Private Partnerships, Participant Handbook, November 2012, Version 2, Central Department for Public Private Partnerships - Ministry of Finance, Republic of Kosovo; page 7-8.

${ }^{6}$ Constitution of the Republic of Albania, Article 82: “(1) The proposal of laws, where appropriate, shall always be accompanied by a report justifying the financial costs for its implementation.
}

Albania, which is based on a market economy ${ }^{6}$. Further, the law regulating the budgetary system in the Republic of Albania, as one of the principles of functioning of the budgetary system, provides for the economical, efficient and effective use of public resources ${ }^{7}$. Likewise, the legal framework enacted to ensure the performance of public administrative functions by administrative bodies emphasizes the importance of the effectiveness ${ }^{8}$ and efficiency of the exercise of the administrative activity ${ }^{9}$.

Albanian Public Private Partnership legislation (abbreviated PPP) ${ }^{10}$, considers the PPP a form of long-term, bilateral $^{11}$ contractual agreement between the contracting authority (public partner) and one or more economic operators (private partner), where the private partner undertakes to provide public services within the scope of competences of the public partner, assuming different levels and extent of risks, at the same time being entitled to be rewarded, in accordance with the contract ${ }^{12}$. According to this legal framework:

- The obligation to provide public services may include, inter alia, the obligation to finance, design, construct a public infrastructure facility, use, operate and maintain an existing or a new public infrastructure facility.

- Risks undertaken by the private partner may be related to financing, construction, availability, operation, management, maintenance and technical risks.

- The right to be rewarded, in accordance with the contract, includes the right to use public works, primarily for the purpose of imposing tariffs or payments on end users and consumers, to receive regular direct payments paid by or on behalf of public partner, or other forms of financial support, including the transfer of contractual and other property rights.

The current law in force (Law No.125/2013, as amended by Law No.88/2014 and Law No.77/2015) is entitled "On Concessions and Public Private Partnerships", while all its provisions regulate concession and public-private partnership in the same way, treating them equally from the procedural point of view ${ }^{13}$. The law itself also stipulates

\footnotetext{
${ }^{6}$ Constitution of the Republic of Albania, Article 11/1: "The economic system of the Republic of Albania is based on private and public property, as well as on the market economy and on the freedom of economic activity".

${ }^{7}$ Law No.9936, dated 26.6.2008 "On the management of the budgetary system in the Republic of Albania", Article 4 "Principles of functioning of the budgetary system": "The principles of functioning of the budgetary system are:...c) economic, efficient and effective use of public resources".

${ }^{8}$ Law No.44/2015 "Code of Administrative Procedures of the Republic of Albania", Article 1 .

${ }^{9}$ Law No.44/2015, Article 18/2: “The administrative procedure shall proceed as soon as possible, but not later than the time limit prescribed by law for it, at the lowest cost to the public body and to the parties, in order to achieve what is necessary for a lawful outcome".

10 Law No.125/2013, as amended by Law No.88/2014 and Law No.77/2015 "On Concessions and Public Private Partnership".

${ }^{11}$ Civil Code, Article 662: "The contract is mutually binding when the parties are mutually obliged to each other".

${ }^{12}$ Law No. 125/2013, as amended "On Concessions and Public Private Partnership", Article 8, par.1.

${ }^{13}$ In all the provisions of the law, the terms "concession" and "publicprivate partnership" appear to be equivalent to one another in the following form: concession / public-private partnership.
} 
that, based on the modes of remuneration that the private partner benefits, as well as the sharing of the main risks, a PPP can be realized in one of the following forms: a) public works concession ${ }^{14}$; b) public services concession ${ }^{15}$; c) public works contract; ç) public service contract ${ }^{16}$.

Under Albanian law, the conclusion of a public-private partnership (or concession) contract goes through several administrative procedural stages:

\section{A. Phase I: Preparatory actions.}

Preparatory actions for the award of a PPP are all activities carried out for the purpose of awarding a PPP contract and which precede the procedure of awarding a PPP. Preparatory actions include, in particular, the following: a) identification of potential concession / PPP projects; b) appointing a concession / PPP commission; c) preparing a feasibility study of a concession / $\mathrm{PPP}^{17}$; ç) calculation of the value of the concession contract / PPP; d) preparation of tender documents ${ }^{18}$.

Preparatory work is very important and especially the feasibility study of the project idea identified. The public authority prepares a summary report which focuses in particular on the necessity and appropriateness of the project idea and considers a wide range of implementation alternatives ${ }^{19}$. Therefore, all alternative technical and economic scenarios, through which the project objectives can be achieved, should be identified in advance.

\section{B. Phase II: Procedure for granting public-private partnerships.}

The procedure for the award of a PPP starts with the publication of the contract notice and ends with the publication of the contract award notice or the decision to terminate the contract award procedure ${ }^{20}$. The criteria on which the contracting authority bases the selection of the most successful bidder are as follows:

(i) the most economically advantageous tender, taking into account and placing relative weightings on criteria such as: (a) quality, which includes technical merit, aesthetic, functional and environmental characteristics; (b) running costs, (c) effectiveness costs, (d) post-delivery service and technical

\footnotetext{
14 "Public works concession" is a financial interest agreement entered into in writing between the contracting authority and one or more economic operators whose object is the performance of works, where the remuneration for the works to be performed consists of the right to utilize the works that are the subject of the contract or of this right together with the payment (article 3, par.2 of law no.125/2013, as amended).

15 "Public service concession" is a written financial interest agreement between a contracting authority and one or more economic operators whose object is to provide services, where the remuneration for the services to be provided consists of the right to utilize the services that are the subject of the contract or of this right together with the payment (article 3, par.3 of law no.125/2013, as amended).

${ }^{16}$ Law no. 125/2013, as amended, Article 8, par.4.

17 Article 19, par.2 and 3 of Law No. 125/2013: "The feasibility study shall contain, in particular: a) the operational summary and general description of the project; b) technical, financial, economic and legal analysis; c) environmental studies and implications in nature; d) accompanying annexes, additions requested, conclusions and recommendations.

${ }^{18}$ Law no. 125/2013, as amended, Article 16.

19 DCM no.575, dated 10.7.2013 "On the approval of the rules for valuation and granting by Concession / Private Public Partnership" (amended by DCM No. 313, dated 27.04.2016 and DCM No.146, dated 22.2.2017), Article 3/4.

${ }^{20}$ Idem, article 22.
}

assistance, (e) delivery date and shipment period or work completion period, (f) service price to final beneficiaries; (g) the amount of the concession fee; ii)_the highest concession fee offered ${ }^{21}$.

\section{Phase III: Contract signing}

The contract defines the rights and obligations of the contracting authority and the private partner, in accordance with the provisions of this law and the legislation in force of the Republic of Albania. Prior to the signature or entry into force of the contract, the contracting authority shall receive from the most successful bidder the guarantees required for the performance of the contract and the security instruments in compensation for the damage that may be caused by the failure of the private partners to fulfill their obligations provided in the contract (promise of payment, bank guarantee, corporate guarantee, bill of exchange, etc.), as these are determined by the tender documents or by the decision to select the most successful bid. The private public partnership contract cannot be concluded for a period longer than 35 years $^{22}$.

\section{TO WHAT EXTENT CAN THE PRIVATE SECTOR INTERVENE IN THE DELIVERY OF PUBLIC SERVICES (PUBLIC PROCUREMENT VS PPP VS PRIVATIZATION)?}

There are some differences in the literature between the terms of public procurement (contracting out), privatization and PPP, qualifying public procurement and privatization as being located at two ends of a segment, representing forms of private sector involvement in the public sector, while placing the PPP-s somewhere in the between of these two ends $^{23}$.

\section{A. PPP vs Public Procurement}

In the case of public procurement (subcontracting of goods/works/services) the private sector is partly involved in providing a service that was previously provided by the public sector itself. In this case there is very little transfer of control or risk to the private sector and there is no significant involvement of the private sector in decision making. Thus, every public entity which assumes the status of "Contracting Authority"24 addresses private operators with the aim of procuring works or services, carrying out an administrative competition procedure ending with a contract. Even if we refer to the Albanian law "On public procurement" (Law No.9643, dated 20.11.2006 as amended), "procurement" refers to an administrative procedure, conducted entirely through unilateral administrative acts, which concludes with an administrative contract. The main purpose of this procedure is to achieve

\footnotetext{
${ }^{21}$ Idem, article 23.

${ }^{22}$ Idem, article 27, 28, 30.

23 Allan, J. R. (1999): Public-Private Partnerships: A Review of Literature and Practice; Bettignies, J. and T.W. Ross (2004): The Economics of Public Private Partnerships.

24 Law No.9643, dated 20.11.2006 "On Public Procurement", as amended, Article 3, par.14: "Contracting Authority" is any entity that is subject to this Law for the implementation of its public contracts. These entities are: constitutional institutions, other central institutions, independent central institutions and local government units..organizations formed by one or more of these authorities or by one or more of these public bodies".
} 
efficiency and effectiveness in the use of public funds ${ }^{25}$ and this is mainly sought to be achieved through equal treatment of tender participants, the conduct of a transparent process, the promotion of competition, thereby ensuring the better use of public funds and bringing together serious and competent market partners.

Of course, unlike other more developed forms of Public Private Partnerships, public procurement carries some of the disadvantages encountered when the public sector provides services itself. Thus the work, service or goods required to be procured are designed to the smallest detail by the public entity itself and the economic operator only strictly applies the public entity's request. Also, despite the saving of public funds (due to ensuring competitiveness), we are still dealing with spending public money and at the same time undertaking no risk from the private sector.

Also we have to mention the difficulties encountered in the process of monitoring and enforcing the procurement contract due to the still very important role of the public administration in drafting technical specifications, stiffening the latter and inability to improve or adapt them with the new circumstances, but also because the private entity somehow lacks self-regulation that occurs naturally when operating with its own funds. On the other hand, in the case of PPP, as mentioned above, we face the shifts in control, authority and decision-making in the private sector. In this case the private partner provides the capital and at the same time is the service provider. So management risk is transferred entirely or partially to the private and this is an advantage.

With PPP, the private operator is required to complete the output (which job or service needs to be performed, what needs to be fulfilled) while with traditional procurement, the Public Authority decides on the input (how many employees will be hired, what to buy, what equipment to maintenance, how many materials will be built, etc.). In this sense, the advantage of PPPs is that the relationship focuses on "what should be achieved" rather than "how it will be achieved". In Public Procurement, capital and operational costs are paid by the Public Authority, which also assumes the risk of exceeding construction costs, as well as delays in infrastructure construction. As for PPP-s, the public sector pays only on the basis of services provided. The private sector finances from its own funds the construction, operation and maintenance of infrastructure. The return on investment is based on the quality of service.

\section{B. PPP vs Privatization}

The difference between full privatization and a PPP agreement is that in the latter the public sector still plays an important role, while in a full privatization the involvement of government is minimal unless a legal framework is needed for the privatized entity. According to Savas ${ }^{26}$, privatization is the act of reducing the role of government and enhancing the role of other social institutions in producing goods and services as well as in maintaining of property rights.

\footnotetext{
${ }^{25}$ Law No. 9643, dated 20.11.2006, Article 1, par.2.

${ }^{26}$ Savas, E. (2000): Privatisation and Public-Private Partnerships
}

\section{REASONS FOR USING PPP IN PROVIDING PUBLIC SERVICES}

The main reasons for selecting PPPs are: (a) Value for money; (b) Instant availability of additional services; (c) Avoidance of Debt and the Public Budget; (d) Higher management, technology and performance.

\section{A. Better value for money for users of public services and infrastructure:}

Bearing in mind the fact that the private sector is not always more effective than the public sector, performance analysis and comparisons are always needed before deciding which option is best. Through a PPP project it is always intended to provide "Value for money", which is the term used to determine whether the contracting authority has obtained the maximum potential profits from the works or services provided by the $\mathrm{PPP}^{27}$. In a PPP project, alternatives to achieving the project objectives are analyzed in advance, comparing whether another contract would be more effective than the PPP. Thus, the public authority, through a feasibility study, is obliged to analyze whether the project designed as a concession/PPP is more economically advantageous than the traditional procurement alternative ${ }^{28}$. Therefore, a PPP provides better value for money to the public (users of public services and infrastructure) because it is presumed that the provision of a public service with a PPP (in terms of economic, social and financial benefit) is evaluated and compared in advance with the provision of a such public service in any other contracting form.

\section{B. Instant service availability:}

This is due to the fact that PPP-s carry out a project which, due to various reasons (lack of budget, lack of experience etc.), cannot be implemented and some time would have to wait or even it cannot be realized at all. In this case, we have more public services available. PPP-s thus ensure the availability of public services to their users, rather than waiting until conditions are created to fund these services from the public budget.

\section{Avoidance of Debt and Public Budget: Attracting private investment in public services:}

By contracting the private sector to implement attractive projects for them, the public budget can be directed towards meeting other social priorities (education, health, etc.). But always be careful that the PPP option first should pass the value for money test.

\section{Higher management, technology and performance in service standards and contract enforcement:}

PPP-s require contracts that contain clear performance standards (based on outputs) to be reached and in cases where the private partner fails to deliver the required services, he is not paid. In this way the private partner has an incentive for better performance, as any mistake will have direct financial costs to him. PPP-s provide access to

\footnotetext{
${ }^{27}$ Law no.125/2013, article 3, par.17: "Value for money"... This term is not limited to the absolute measure of the value of the works/services but also includes the evaluation of quality, cost and resource utilization, suitability with the purpose and objective of the contract, time and opportunity to decide if all these elements combined make the best economic value".

${ }^{28}$ DCM no.575, dated 10.7.2013, as amended, article 4, par.2.
} 
new technologies and experienced management, especially when implementing a project that has not been present in the country before. Experience has shown that by making service providers responsible for achieving certain performance standards, the frequency of problems in service delivery decreases (risk and problem prevention).

\section{Challenges For A QUALITY AND EFFECTIVE} IMPLEMENTATION OF THE PRIVATE PUBLIC PARTNERSHIP

In spite of the necessity of PPP, implementation in practice has raised some issues that need constant attention for an effective implementation of this partnership:

1. An important requirement of European law (acquis communitaire) remains the non-violation of free market principles and ensuring the competition. This issue is of particular importance especially in the process of selecting private partners or even in determining the terms of the contract renewal. These are agreements extended in time due to the large initial investment made by the private entity and its guarantee of return on investment. The duration of the partnership certainly carries the risk of creating a closed and non-competitive market. This is one of the reasons that adherence to selection procedures and rules ensuring competition, transparency and proportionality is crucial in a PPP.

2. The main purpose of the selection process is to reduce production costs although simultaneously the problem of maintaining the quality of service is raised. Determining the quality of service remains difficult especially in the case of public services where the relationship between input and output is often unclear. At the same time, this requires continuous and active monitoring of the management of this service due to the monopoly granted to the service provider in a particular area.

3. On the other hand, this partnership itself faces many risks that are common during the implementation of a project. They include ${ }^{29}$ :

- technical risk, due to design failures;

- the risk of construction, which may result from exceeding deadlines and cost overruns;

- operation risk, resulting from high maintenance and operation costs;

- income risk, as a result of lack of service demand;

- financial risk, the result of financial costs;

- environmental risk due to the impact of the project on the environment;

- political and legal risk as a result of legal changes or unsupported government policies;

- the risk of force majeure.

4. The most critical issue for PPPs remains the concern of whether service delivery revenues can cover operating and financial costs and can provide return on investment.

1. There are already some factors that can lead to PPP

${ }^{29}$ Grimsey, D. and M. Lewis (2004): Public-Private Partnerships: The Worldwide Revolution in Infrastructure Provision and Project Finance. failure ${ }^{30}$ :

- Poor public partner organizational structure: The public partner can often be poorly organized and rigid (bureaucratic), especially in unstable states.

- Lack of clarity: occurs when the private partner is not clear at first stage about the purpose of the project and its results.

- Inadequate communication: such communication between the government and the contractor can lead to project failure, as their agreement on human, financial and material resources is necessary to achieve the objectives.

- Inadequate PPP structure: PPP types differ mainly due to the level and nature of the risk transferred to the private sector. One mistake often encountered in this regard is when the risk of demand is transferred to the private sector even though this contractor has no control over the level of the use of infrastructure which is contracted. Partners (public and private) are advised to share the risk depending on their ability to manage it. An appropriate risk sharing allows governments to tailor PPPs to specific situations and infrastructure sectors. A better understanding of PPP models helps to solve complex issues and properly select the level of risk sharing.

- Lack of internal capacity: occurs when both the government and the private contractor do not meet the required criteria of staff capability needed for PPP management.

- Inappropriate planning: the success or failure of a PPP is often linked to the initial PPP design, policies, legislation, etc.

- Lack of focus on operation: the government can see PPP as merely a financing instrument and thus focus on the moment of the transaction rather than on operating the instrument of infrastructure.

- Failure to understand the value for money: occurs when the costs of Bank loan or tendering related to PPP are not sufficiently covered by profits or when government employees do not properly understand the concept of "value for money".

In order to avoid these risks, governments can adopt a partnership life cycle that gives due attention to all phases of a PPP, from planning, transaction to PPP management ${ }^{31}$.

\section{CONCLUSIONS}

Public-private partnership implies another step forward in relations between the public and private sectors, as long as it is regarded as the best procurement infrastructure of goods and services for public sector. Beyond various interpretations of this concept, public-private partnerships are seen as the primary form of relationship between the two

\footnotetext{
${ }^{30}$ Deloitte Research (2006)

${ }^{31}$ Idem.
} 
main sectors of a country's economy. This relationship is builded on the professionalism of each party, which makes it the best one to meet the public needs through the allocation of resources, risk and benefits. What all this reflects is the fact that the public sector or, more precisely, its various institutions have passed from the owner or producer of the goods to the purchasers of these goods from the private sector. A PPP is an arrangement, an administrative contract between the public and private parties, which involves the sharing of risk, responsibility and profit and is undertaken only when providing value for money to taxpayers. The PPP model figuratively is placed somewhere in the between of two other forms of private sector involvement in the public sector, which are public procurement and privatization.

One of the challenges of the legal regulating of PPPs is that one of the participants in the PPP projects is a public authority, which entails the need to introduce a public accountability mechanism different from those situations where all participants are private. But on the other hand, one of the reasons for establishing a PPP is to escape from the political and bureaucratic processes that arise when dealing with entirely public activities. To balance this situation of the need to introduce a public accountability mechanism and the need to keep public bureaucracy away, some dilemmas arise which the legal framework has to resolve: how will public and private requirements, that can cause conflict, be balanced? Can government organizations be transformed from buyers of infrastructure assets into long-term contractual managers in the construction and administration of these assets? What are the administrative requirements to achieve these equilibriums?

Finding a formula such as PPP in Albania, which strives to combine the most positive elements of the two sectors, will prove successful if it succeeds in simultaneously realizing the profit or return of private investment on the one hand and on the other hand providing quality service to the citizen (client) and fulfilling the "public interest". In fact, I believe that these two sides are closely linked and interdependent, which at the same time constitutes the strength and the risk of this partnership. The vulnerable aspects for this type of partnership in Albania are firstly, finding of a "common language" between two sectors with different objectives, which even apart from each other present problems of normal functioning and secondly, the monitoring and transparency of this type of partnership, which particularly in transition economies risks creating hotbeds of corruption and abuse. For this reason, the establishment of efficient legal control mechanisms takes priority on the the legal framework in Albania.

Albanian legislation considers PPP as a form of long-term cooperation, regulated by a bilateral contract, between the contracting authority and one or more economic operators, where the private partner assumes the obligation to provide public services within the scope of the public partner's competencies, undertaking different levels and extent of risks, while having the right to be rewarded, in accordance with the contract. What such a contract should provide is: private capital (surplus), which means public debt and budget avoidance; alternative managerial and implementation skills; value added to the consumer and the public; better identification of needs and optimal utilization of resources; higher quality management and technology and also higher performance in service standards and contract implementation.

In spite of the necessity of PPP, implementation in practice has raised some issues that need to be constantly addressed by the legal framework, for the most effective implementation of this partnership, which are: noninfringement of free market principles and ensuring competition; safeguarding of the quality of public service; the different risks that the partnership faces; the revenue from the service delivery should cover operating, financial costs and ensure the return on investment.

Factors that can lead to PPP failure are: Poor public partner organizational structure; Lack of clarity; Insufficient communication; Inadequate PPP structure; Lack of internal capacity; Inappropriate planning; Lack of focus on operation; Failure to understand the value of money. In order to avoid these risks, the government may adopt the legal framework to provide a partnership life cycle that gives due attention to all phases of a PPP, from planning, transaction to PPP contract management.

\section{REFERENCES}

OECD (1993): Public Menagement Development Survey. Paris

New South Wales Treasury (2009): New South Wales Public-Private Partnership-An Evolution

OECD (2009): Bridging State Capacity Gaps in Situations of Fragility

Introduction to Public Private Partnerships, Participant Handbook, November 2012, Version 2, Central Department for Public Private Partnerships - Ministry of Finance, Republic of Kosovo.

European Commission 2003: Guidelines for successful public-private partnership.

Deloitte Research (2006)

Allan, J. R. (1999): Public-Private Partnerships: A Review of Literature and Practice; Bettignies, J. and T.W. Ross (2004): The Economics of Public Private Partnerships.

Savas, E. (2000): Privatisation and Public-Private Partnerships.

Grimsey, D. and M. Lewis (2004): Public-Private Partnerships: The Worldwide Revolution in Infrastructure Provision and Project Finance.

Constitution of the Republic of Albania.

Law No.9936, dated 26.6.2008 "On the management of the budgetary system in the Republic of Albania".

Law No.44/2015 "Code of Administrative Procedures of the Republic of Albania".

Law No.125/2013, as amended by Law No.88/2014 and Law No.77/2015 "On Concessions and Public Private Partnership".

Directive 2004/18/EC of the European Parliament and of the Council of 31 March 2004 "On the coordination of procurement procedures for the award of public contracts for works, supplies and services", CELEX number 32004L0018, Official Journal of the European Union, Series L, no.134, dated 30.4.2004.

Civil Code of the Republic of Albania.

Law No.9643, dated 20.11.2006 "On Public Procurement”, as amended.

DCM no.575, dated 10.7.2013 "On the approval of the rules for valuation and granting by Concession / Private Public Partnership" (amended by DCM No. 313, dated 27.04.2016 and DCM No.146, dated 22.2.2017). 